\title{
Election, Politician and Corruption: A Critical Discourse Study in Two Indonesian Newspapers Covering the Ruling Party Leader Corruption
}

\author{
Nostal Nuans Saputri \& Catur Suratnoaji
}

Brawijaya University, Jalan Veteran Malang, East Java, Indonesia

nostalnuanssaputri@yahoo.co.id

Universitas Pembangunan Nasional (UPN) Veteran, Surabaya, East Java, Indonesia

catur_sa@yahoo.com

\begin{abstract}
The aim of the study is to construe the discursive strategies and to probe for ideological goals behind the two national newspapers text constructions about the former ruling Democrat Party leader, Anas Urbaningrum, corruption case before the 2014 general election. The analysis of this study adopts a critical perspective on discourse analysis (CDA) specifically the Teun Van Dijk's socio-cognitive approach. The texts are divided and analyzed into three levels, namely: text, sociocognitive of the text producers and social context surround the discourse production. The study concludes three important points. First, both newspapers were intensively presented news about corrupt politicians before the 2014 general elections. One of which was the ruling Democrat party leader, Anas Urbaningrum (AU) corruption case. Second, Seputar Indonesia daily (hereafter SINDO) texts are defending AU by presenting very systematic and consistent discourse patterns even after the Corruption Eradication Commission (KPK) named AU a suspect in corruption and money laundering cases. The patterns are disagreements of the Anas political rivals accusation, exaggerating internal conflict between Anas and his political rivals, attacking others' contra opinion and defending AU position through its news texts; while, on the contrary, Jawa Pos daily (JP) emphasizing law enforcement for AU corruption case. It presents accusation and attacking comments from some party senior cadres to AU, pools results about the Democrat Party popularity and electability that dropped significantly because of corruption issue, and it also provides statements mostly from the graft commission about AU case law enforcement.
\end{abstract}

Keywords: Election, Corruption Discourse, Politician, Media, Critical Discourse Study

\section{Council for Innovative Research}

\author{
Peer Review Research Publishing System
}

\section{Journal: Journal of Social Sciences Research}

Vol. 8, No.1

jssreditor.cir@gmail.com

www.jssronline.com 


\section{INTRODUCTION}

Media provides various informations to the society. However, even though news programs are widespread in media, we cannot get all information we need. As Bennett (1998) argues, "the point is that the news we are given is not fit for democracy; it is superficial, narrow, stereotypical, propaganda-laden, of little explanatory value, and not geared for critical debate or citizen action" (p.9). Media set their own rules to govern their agenda. Kim (2014) explains that whatever presented in the news is selected according to a set of criteria and values, which is carefully constructed in order to support a certain interest. As a consequence, the reporters are affected by a wide web of influence on how they select the event and how the cover it, therefore Borchers (2005, p. 119) argues that news media do not operate in a vacuum.

It is crystal clear for mass media researchers that the news is no more than a "product" that is sold to the public. The news organization selects events or issues that will attract the largest audience which all comes down to generate profit. In constructing news, Vincent Mosco (2009) argues, media commodify the content. Further he explains that commodification is "the process of transforming things valued for their use into marketable products that are valued for what they can bring in exchange" (2009, p.127).

News, as Borcher quotes from Bennett (2005), directs public attention to scandals, careers, personal wins and losses, prestige and status. One phenomenon which exemplifies Bennett's statement is Indonesian media coverage about former Democrat Party general chairman, Anas Urbaningrum's, graft scandal. The scandal first appeared to public in 2012 after the former Democrat party treasurer Muhammad Nazaruddin mentioned Anas being involved in the corruption trial of the SEA Games Athletes' Village (Wisma Atlet) construction project in Palembang (Uu, 2012). The issue gained larger attention as the party, who won the election twice, prepared contested in the 2014 general election.

A survey published by Pol Tracking Institute in January 2014 mentioned that throughout 2013, Democrat was the second most frequent party reported for corruption issue (Baskoro, 2013). Further, from another survey conducted by the Indonesian Institutions Indicator in 2013, Anas' name was cited 10,656 times in the news about the corruption of elite political party in the range of January to December 2013 (Auliani, 2013). Still according to the same survey, the number far exceeds the number of news about other corrupt politicians, for example, the former Democrat Party Treasurer Muhammad Nazaruddin and former President of Prosperous Justice Party (PKS) Lutfi Hasan Ishaq (Auliani, 2013).

From the preliminary study, the author concludes that in reporting Anas case, the Indonesian media agenda were split into two points: the internal political conflicts that led to the legal scenario through the exposure of Anas alleged corruption case and legal enforcement of corruption act which was purely beyond the internal conflict. This article focuses on revealing the media (SINDO and JP) strategy to stipulate Anas' corruption case terminology based on their perspectives through discourse that seemed natural. In addition, it tries to construe the ideological purpose as well as the hidden power behind the text production of Anas Urbaningrum corruption case in JP and SINDO.

\section{Theoretical Framework: Critical Discourse Study and Corruption Discourse}

Corruption is not a new phenomenon. Breit (2011) mentions historical records that the phenomenon has emerged since the 4th century BC; while in Indonesia, Wijayanto (2009, p. 4) describes "corruption has occurred since the kingdom era, even the Dutch East Indies Companies (VOC) which dominated the trade in Dutch colonial era, went bankrupt in the early 20th century due to rampant corruption in its organization". Prasetyo $(2013$, p. 5) quotes a recent research conducted by PERC (Political and Economic Risk Consultancy). It is said in the research that Indonesia is one of the emerging market stars in 2010 as the investment destination for business which became the most corrupt countries among 16 Asia Pacific countries. To overcome this, the Indonesian government is currently active in conducting deterrence of corruption one of which is to establish and reinforce the existence of the Corruption Eradication Commission (KPK).

It is not just the government who addresses the corruption issue but also scholars from many disciplines; however it is mostly done by Indonesian law scholars such as OC Kaligis in 2008. Research on corruption from the perspective of language and communication studies are still rare. Among the few studies of corruption from the perspective of language and communication science that the author found from literature review are the study of the senior anti-corruption journalist Mochtar Lubis' analytical overview about bureaucracy during the old order and the new order (Semma, 2008), and a study of the phenomenon of communication networks in corruption (Antoni, 2014).

In contrast, corruption studies from the social science perspective abroad have been done considerably. One example of the study is Feraz and Finan's (2008) study about the effects of the media publication of the incumbents' audit results who are involved in corruption. The study found that the electability level of the corrupt legislative candidates was decreased after being published into the media. The next research is the corruption discourse research by Rocha, Brown, and Cloke (2011). By combining the perspective of critical Geography and critical Business, they tried to explore the use of certain Nicaraguan politicians' discourse in order to justify and legitimize corruption. Due to the fact that there are only few number of media corruption discourse studies, the author feels the need for deepening the understanding of how media embed corruption terminology in society. The first reason based on Breit's (2011) contention that the media is a medium in which the discourse of chronological or process of a corruption acts is being discussed. Furthermore, media reports the result of corruption, emphasize it and reproduce it to the public several times. Second, being exist in a democratic country means that Indonesian press has a freedom to set their editorial policy and agenda. They can choose to be an opponent or supporter of the government policy against corruption. As Dharmasaputra $(2009$, p. 696$)$ claims that in democratic countries, the media is considered to have an important role-together with the civil society groups-to facilitate public discussion about what should and should not be committed, and to criticize the government in dealing with corruption. 
In a critical paradigm, media is not considered as a neutral entity. It can be controlled by the dominant groups, and they can instill their ideology through the knowledge that embedded in texts and talks in order to persuade the public. In order to reveal the hidden ideology that brings the inequality, the author applies critical discourse study in analyzing the media text about Anas Urbaningrum corruption case. Critical discourse study is a type of discourse analytical research that primarily studies the way social power abuse, dominance, and inequality are enacted, reproduced, and resisted by text and talk in the social and political context (Van Dijk, 1988b). Further, Machin and Mayr (2012) suggest that by using the method, a researcher can conclude the dominant group or the text producer's ideology and point out where the ideology may be hidden.

There are various factors that influence the production of media content from individual media workers, media routines, institutional influences (ideology and economic factors) and external factors (Shoemaker and Reese, 1996). Those all factors understood, memorized, and applied by media workers from their cognitive process. Therefore, the author applies Van Dijk's Socio-Cognitive approach in examining the JP and SINDO texts about the former Democrat Party Chairman Anas Urbaningrum. In Van Dijk's view (2013), social cognition is a representation of beliefs, perceptions, knowledge, and the media workers' that may provide bridge between the analysis of text structure, and social context. By using the Van Dijk's model, this study is able to describe the ideological purposes of news text producers in the discourse on corruption Anas in JP and SINDO.

\section{METHOD}

The author adopts Van Dijk social cognition model. Data were collected by scrutinizing the texts, in-depth interviews, and literature reviews. The research subjects were Jawa Pos newspaper published in Surabaya and SINDO daily published in Jakarta. The unit analysis in this study is the news texts about Anas Urbaningrum corruption case in JP and SINDO during February 2013. There were 10 news texts being analyzed. The informants are chief editor, deputy chief editor, and political desk editor, political reporters who reported Anas Urbaningrum corruption case, Anas Urbaningrum, and Indonesian Institute of Science (LIPI) political observer lkrar Nusa Bakti. Based on the model, the author analyzed texts into three levels: text, social cognition, and social context. The following are the detailed step in data collection and analysis.

Table 1: Discourse Elements Research Method by using Van Dijk's Model

\begin{tabular}{|c|c|}
\hline Structure & Method \\
\hline $\begin{array}{l}\text { Text } \\
\text { Analyzing the media } \\
\text { discourse strategies in producing } \\
\text { news text about Anas' corruption } \\
\text { issue. }\end{array}$ & $\begin{array}{l}\text { Critical Linguistics, i.e. examining the three linguistic } \\
\text { elements of the texts. } \\
\text { a. At the macro-structure, the author analyzed the } \\
\text { global meaning of a series of news related to } \\
\text { Anas Urbaningrum corruption case presented by } \\
\text { JP and SINDO. } \\
\text { b. Then, at the superstructure level, the author } \\
\text { examined the news text writers' strategies in } \\
\text { preparing the text frame pattern. This level shows } \\
\text { the text writers' stance. We can conclude that } \\
\text { from the composition of a text frame, namely: } \\
\text { introduction, contents (setting place and time, } \\
\text { orientation, complication / conflict), and the } \\
\text { conclusion (problem solving, evaluation and } \\
\text { coda). } \\
\text { At the micro level, the author peruses the } \\
\text { linguistic grammar of Anas Urbaningrum } \\
\text { corruption texts. In this level, the author obtains } \\
\text { respectively a phonological, morphological, } \\
\text { syntactic, and semantic description of sentences } \\
\text { as well as the rhetorical aspect of the texts. }\end{array}$ \\
\hline $\begin{array}{l}\text { Social Cognition } \\
\text { Analyzing how the news text writers } \\
\text { understand the issue of former } \\
\text { Democratic Party chairman AU } \\
\text { corruption, how the media workers' } \\
\text { individual ideology, media routine and } \\
\text { external institution including the news } \\
\text { sources affect the news constructions. } \\
\text { By examining those aspects, the } \\
\text { author is able to point out the power } \\
\text { and ideologies behind the text } \\
\text { production. In addition, the author can }\end{array}$ & $\begin{array}{l}\text { In-depth interview: } \\
\text { a. With } 6 \text { informants, among others are: journalists, } \\
\text { editor and chief editor. The focus of the interview } \\
\text { are the editorial consideration in selecting the } \\
\text { point of views in Anas' case, the news writer } \\
\text { educational background, political affiliation (both } \\
\text { as student or when they have worked in the } \\
\text { media), their involvement in the Muslim Student } \\
\text { Association (HMI) as Anas did, the media } \\
\text { workers' reporting experience (political desk and } \\
\text { another desk), the duration of introduction and } \\
\text { interaction with AU, how the interaction with }\end{array}$ \\
\hline
\end{tabular}




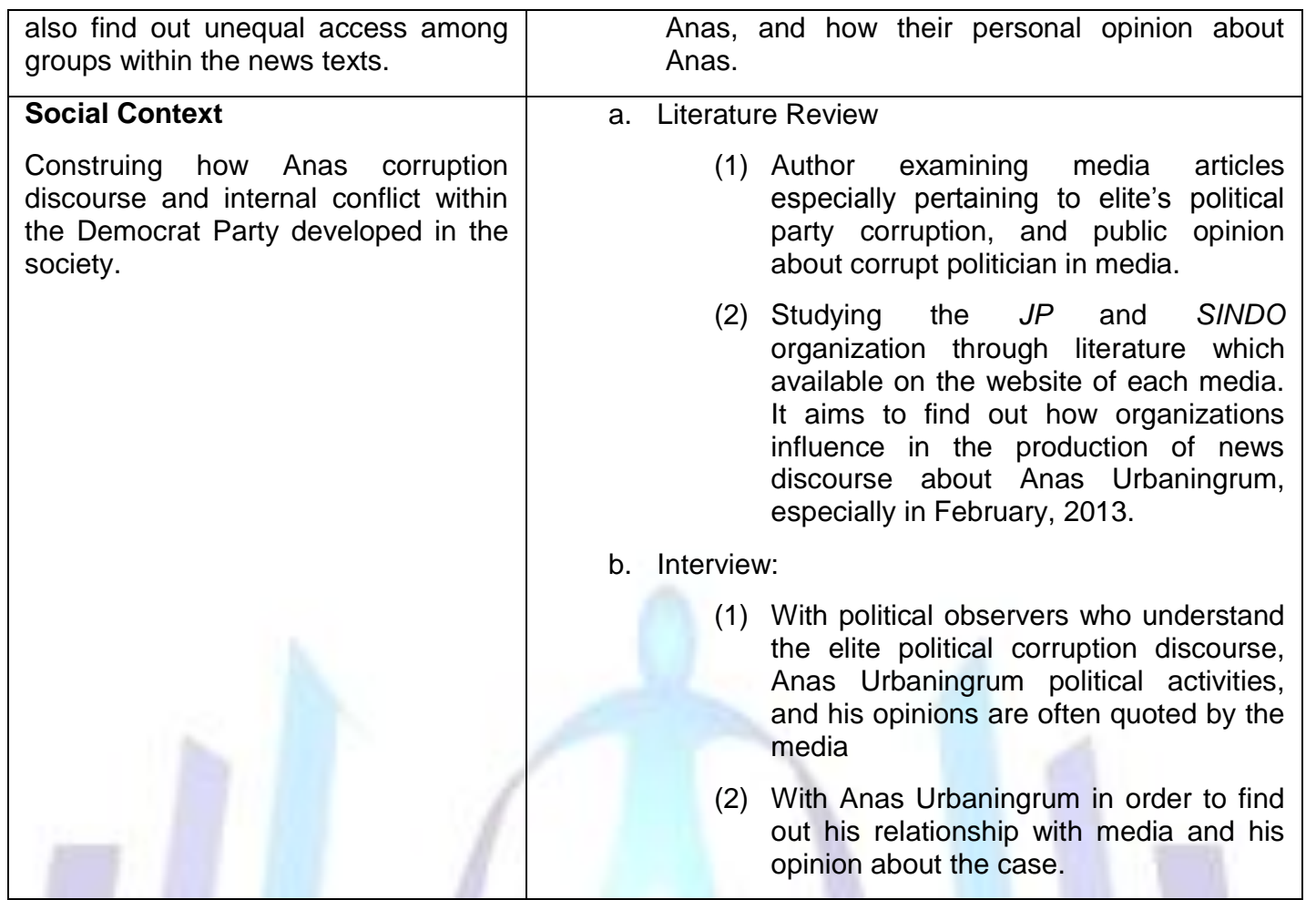

\section{Results}

\subsection{Corruption Discourse Strategies in Jawa Pos and SINDO Daily}

The first phase of the analysis is analyzing the linguistic categories of news texts. At the macro text level, the author finds that JP presents two global themes. The first, Anas corruption scandal is one precedent that jeopardizes the Democrat Party's electoral prospect. It then caused internal conflict in Democrat Party. Second, Anas alleged involvement in Hambalang corruption scandal needs a serious attention from the government and public as same as other politicians' corruption cases.

In superstructure level, the author finds that the news writing pattern in JP resembled an inverted pyramid in which the most important information placed in the beginning of the news (title and lead); while the background or supporting information are presented at the body of the news text. As described previously, the author concludes that at the beginning of the news, JP generally presented information about internal conflict between AU and some senior cadres in Democrat Party due to corruption issue that led to the decreased level of the party's electability. The conflict eventually, brought up a plan to hold an extraordinary congress (KLB) in order to replace Anas. Furthermore, JP presented information about the Corruption Eradication Commission (KPK) efforts to investigate Hambalang corruption case which allegedly involving $\mathrm{AU}$.

At the micro element, by analyzing the stylistic styles of the language use, the author finds some words choice used by the journalist to indicate his position in supporting the KPK to investigate Hambalang corruption case thoroughly. It also includes imprisoning AU when he considered guilty in the case. Besides, explicitly, JP's selected vocabularies also show that KPK is not an institution that can be intervened by political forces. Those are "KPK did not respond to Susilo Bambang Yudhoyono (SBY) Inquiry", "SBY Takes Over Democrat", "KPK Leaders Agree Anas Suspect", "KPK Named Anas Suspect Over Corruption." In order to support their stance that explicitly shown in the news titles, JP provided some rhetorical signs. One of which is caricatures resembled domino card that represents the faces of all Hambalang corruption suspects. The cards were arranged facing each other and then crashed after colliding. The latter fall was the card that contained AU's face.

The macro level analysis in $J P$ finds that $A U$ corruption issue has jeopardized the party's reputation, the author finds different global theme in SINDO. From the analysis, the author infers that AU corruption issue that developed publicly is no more than a part of political scenario to force AU steps down from his position as the party general chairman.

At the superstructure level, SINDO performed very systematic and consistent news schemes. In the news titles and leads that functioned as the summary of the news, SINDO explicitly revealed efforts of some senior cadres to force AU resignation several times. The author finds, SINDO wrote some hyperbolic sentences which based on the beginning of $A U$ political career in Democrat Party. One example of the statement can be found in the title of news, i.e. "SBY Dislodges Anas Power" (Syarief, Ahmad \& Sahid, 2013). The main purpose of the title is to shape readers' cognition and bring understanding that $\mathrm{AU}$ accusation is a part of political sabotage. 
Further, the main story contains details of background information that aim to strengthen the claim that was built by SINDO since the beginning of the news. In achieving their purpose, in the news body, SINDO provided many political observers' comments about series of political events happened before AU was named suspect. In addition, SINDO also several times cited political observers who stated that the SBY's effort to ask KPK immediately clarified AU legal status is a form of political intervention. It confirmed that the issue of AU corruption scandal is more political than legal.

In micro level specifically at the semantic aspect, the author finds coherence among sentences. It means that each sentence is written to explain in detail and support sentences that written previously. It can be seen from the given background political stories when AU was dismissed from his position as the party chairman as well as when KPK declared AU legal status.

From the syntactic analysis, SINDO always represents $A U$ as a positive and a potential leader. In contrast, AU senior political rivals are depicted as a negative, yet powerful entity that endangering AU position. Furthermore, to represent social actors in the text, SINDO indicates that AU faces a group of people who want to force him back. One example is the news entitles "Senior Democrats Shakes AU" (Sahid, 2013). In this sentence, SINDO did not mention specifically who and how many people who want Anas resigned from his position. It only mentioned those who wanted AU stepped down were Democrat senior cadres.

Next, from the stylistic aspect, the author finds some word choices that indicate a presumption of political scenario behind AU suspect status. The choice of words, for example can be found in the SINDO headline on February 6, 2013, i.e. "The urge AU Stepped Down is Systematic". There is no definite subject which means the journalist wants the readers to conclude themselves after finished reading the news. In addition, the word systematic means well-planned or arranged orderly.

\subsection{Social Cognition of JP and SINDO Reporters}

In order to comprehend the text message, a discourse analyst needs a bridge to connect the texts with the text production and the social realities. A bridge that Van Dijk (1988) offers is having the text producers' cognitive analysis. He argues that the analysis can explain how newsmakers continuously and routinely summarize the myriad of source texts (other media messages, wires, interviews, reports, or press conferences) that are used in the production of a specific news report (1988, p. 14). At this stage, the author finds some factors that affect journalists in writing news about the ex-chairman of Democratic Party corruption case.

First is individual media workers factor. All JP informants admit that they know AU even though they have no close relationship with him. As political journalists, the informants claim that they have known AU since he was elected as chairman for political affairs in the party's central representative council (DPP). They stated that they admire AU's expertise and politeness in politics. One informant, $\mathrm{H}$, said that he had heard Anas cleverness in politics since he became an activist in the Islamic Students Association (HMI) because the informant was also the HMl activist when he entered his undergraduate degree in a state university. A similar opinion also stated by $A$, the other informant. He said that $A U$ is a potential political leader because he was not an instant political leader. Still according to A, AU had prepared his political career for so long. He even became the member of drafting team for the establishment of KPK back in 2002.

All of the positive perceptions about $\mathrm{AU}$ as a young polite honest and clever politician that the informants felt suddenly changed when the former Democrat Party treasurer Muhammad Nazaruddin mentioned his involvement in Hambalang corruption scandal. The informants stated that they began to report the news about Anas carefully. They claimed that they want the law enforcement against corruption issue open to the public at one side, and maintain their professional relationship with Anas as their news source at the other side. Besides, D, the informant who in charge of reporting Democrat Party's political activities admitted that his editor gave him freedom to choose the angle about AU case.

A similar statement was expressed by JP political editor who also became the author's informant. Regarding news content about AU case, he stated that as an editor he constrained by ethical guidelines as determined by the journalists association (PWI-AJI) as well as his self censorship; whereas, to define the angle he was directed by the market interest and the need to expose law enforcement to Hambalang corruption scandal. It brings out conclusion that the media profit was the most factors that influence JP editorial policy in Anas corruption news. Further, regarding the meaning of selfcensorship, informant $\mathrm{H}$ added that although he had no spesific directions from his editor or chief editor in writing Anas case, he had to avoid making attacking news to President Susilo Bambang Yudhoyono. Due to the fact that in spite of SBY position as the chairman of Democrat Party Advisory Board, he was also a president who appointed the former JP CEO Dahlan Iskan one of his ministers. About the influence, Van Dijk argues that "True, media owners often do not interfere directly in news coverage, although there are many examples of such interference as is the case of Ruppert Murdoch in his newspapers"..."In other words, the influence is indirect, via de knowledge of editors and reporters about the dominant ideologies of owners and chief editors".

In contrast to JP editorial policy, SINDO chief editor, S, admitted that the editorial policy about Anas alleged corruption case was determined through editorial meeting. He said that in selecting the editorial stance, the editor boards considered several aspects. The first was AU rapid career in Democrat; one indicator was when he won the internal election as the general chairman of the party. While in fact, at that time, SBY as the chairman of Democrat Advisory Board had another candidate. S saw this as a potential cause of SBY disliked. Second, in S views, AU was a leader who had very strong grass root supporters. $S$ considered that as a threat to Anas rivals in Democrat. Third, there were mass publications that linked the Anas corruption issue with the party's decreased electability level even before any legal decision by the law institution. Fourth, although Anas case had emerged since the beginning of 2012, until the beginning of 2013, AU had not been detained by KPK. 
With those considerations plus with the experience of intensive interaction with Anas since before becoming the SINDO chief editor, informants S, said that SINDO finally decided to select angle in defending Anas. Commenting about his editorial policy about Anas, $\mathrm{S}$ claimed that the majority of Indonesian media had committed trial by the press in reporting Anas legal case. Therefore, he chose to consider various aspect in evaluating a case.

\subsection{Election and Corrupt Politician}

Before the 2014 general election, elite politician corruption issues made daily headlines in Indonesian media. Many political and law observers consider the rampant politician corruption in Indonesia is due to the high political cost. A founding chair of the Democrat Party, Budi Santoso, told a political professor from Australia Thomas Reuter (2014) that Indonesian politicians have to mobilise the masses, feed them, and pay for their transport, therefore the cost of doing politics in Indonesia is very high, beyond their capacity; While in fact party contributions are not appropriate, businesses can only give up to 7 Billion Rupiah (690,000 AUD) (Reuter, 2014). In addition, the political costs continue rising due to the fact that the campaigns become more professional nowadays. Therefore, the political candidates should hire more professional staffs.

In order to follow the election process until successfully elected, the former Chairman of Indonesian Constitutional Court (MK) Mahfud MD, argues that the legislative candidates or the prospective regional leaders must prepare large sums of money (2013). Still according to Mahfud, they need the funds to give the party "political dowry", to pay for the campaign, createe banners and billboards, advertise on television, visit constituents, prepare a dawn raid (money politics), wages for political consultants and the cost of the survey until the honorarium for the witnesses at the poll. Consequently, every candidate must use their all assests. Therefore, when they finally elected, their top priority is find the funds to recover the capital they had acquire for an election.

Furthermore, one of the empirical evidence that also shows the high velocity of money in politics is the increased spending on advertising, especially political parties before the 2014 election. It is stated by Managing Director Nielsen Indonesia, Irawati Pratignyo, that the value of ad spending by political parties and local governments during the first half of 2013 rose 56 percent over the same period in the previous year (Prworld, 2013). According to the same source, the ads functioned as publication for legislative candidates, president candidates or political party figures.

Agree with the previous comments and research finding, the author informant from $J P$, D, who has long been a political journalist, confirmed public agreement that political party activities especially during the election period were like a vicious circle (personal communication, July 27,2013 ). In his view, someone needs tremendous political funds in order to run for election in todays' election system. Therefore, politicians and parties should seek ways to earn money inevitably. D Seeing the fact that many politicians were detained for corruption, according to D, "So it's not surprising then that many politicians who take a shortcut with corruption, especially when they were in power" (personal communication, Juli 27, 2013).

Return to Anas corruption issue, the ex general chairman of Democrat Party confessed that he was a victim of a political grand design. To the author, Anas said that, "After determined as a suspect, KPK started to find evidence, any evidence. Many people were called as witnesses. If it was possible, KPK might even call a dead person to be a witness" (Urbaningrum, personal communication, December 12, 2013). More details, he explained that the evidence which KPK used as the basis of his Hambalang suspect status was fickle. Nevertheless, the developed public opinion suggests that Anas really enjoy the fruits of corruption Hambalang project. Commenting on this, Anas argued, "Opinion barrage is a precondition of criminalization" (Urbaningrum, December 12, 2013).

\section{Conclusion}

The study concludes that SINDO texts are defending AU by presenting very systematic and consistent discourse patterns even after the Corruption Eradication Commission (KPK) named AU a suspect in corruption and money laundering cases. The patterns are disagreements of the AU political rivals accusation, exaggerating internal conflict between $A U$ and his political rivals, attacking others' contra opinion and defending AU position through its news texts. SINDO represents AU as weak figure, while SBY and some senior Democrats rival cadres portrayed as strong, arrogant and tried to tackle AU political career in the Democratic Party. Confirmation from senior politicans from Democrat concerning the AU forcing down scenario deliberately obscured

On the contrary, JP emphasizes law enforcement for AU corruption case. It presents accusation and attacking comments from some party senior cadres to AU, pools results about the Democrat Party popularity and electability that dropped significantly because of corruption issue, and it also provides statements mostly from the graft commission about AU' case law enforcement.

All authors' informant agreed that their job as journalists is to provide as accurate information as possible to educate the public. They also agreed that for corruption cases involving politicians needed a strict social control so that the law enforcement could work as it should. But, the realization becomes different when they have to follow the editorial policy. $J P$ focuses on the legal discourse but the angle selection is not solely due to the desire of journalists to provide information about law enforcement of a high profile corruption case. In Anas case, the media workers have to obey the rules of creating a selling news and considering the media owner's political affiliation.

Meanwhile, in SINDO, angle selection based on 'selling points' is not revealed. Informants in SINDO asserted that they are more focused on political discourse in the belief that AU was innocent and he was just a victim of a political scenario from SBY and his supporters, therefore AU needs to be defended. The SINDO editorial board get the conviction from their prolong and intense interaction with $\mathrm{AU}$ even before the case emerged to public. 
In a social context element, it appears that the media become the ideological struggle arena. Each side involved or concerned with AU corruption case wants to establish its hegemony over the case. This can be proven by the emergence of the political scenario discourse behind AU suspect status in SINDO newspapers and on the importance of a corrupt politician to be judged in accordance with the corruption law as reported by JP daily.

\section{Suggestions}

Based on the previous discussion, the following are some suggestions that the authors want to propose:

1. Future researchers are expected to take a more intensive research to the media owners so that they can map out precisely the owners' ideology.

2. In order to be able explore more on social cognition of news reporters or text producers, future researchers should conduct participant observation in order to determine the extent of proximity between journalists and news sources and how journalists dig news.

3. Depth interviews with text producers directly related to the production of discourse are needed to obtain a complete picture about the production of a text discourse.

Researchers consider the need for an analysis of the broader social context, not only through literature searches, interviews with experts or observers who mastered a particular issue, but also through social media networks. The uses of social media as a platform for opinion sharing as well as providing information are increasingly intensifying recently.

\section{ACKNOWLEDGMENTS}

We wish to thank to our informants both in Jawa Pos and Seputar Indonesia daily as well as Mr. Ikrar Nusa Bakti, the senior political scientist from Indonesian Institute of Science (LIPI). In addition, we would like to aknowledge Mr. Anas Urbaningrum for his opinion and background story that enrich the social political analysis of this research. Our special thanks also go to Mr. Teun Van Dijk who brings a lot of his knowledge and experiences related to CDA as the basic foundation of this research.

\section{REFERENCES}

[1] Antoni. 2014. Pemberantasan korupsi di Indonesia: Gerakan di tengah sepinya kajian akademik mengenai korupsi (Combating corruption in Indonesia: Movement in the middle of desolate academic studies on corruption). The article was read on a scientific oration in the 10th Anniversary of Social and Political Sciences Faculty, Brawijaya University, Malang.

[2] Auliani, P. (December 10, 2013). Anas dan Akil, fenomena berita korupsi 2013 (Anas and Akil, 2013 corruption news phenomena). Kompas. Retrieved from http://nasional.kompas.com/read/2013/12/10/1151230/

[3] Baskoro, A. (2013, April 17). Menangkap geliat pemberitaan partai politik sepanjang 2013 (Counteracting twisted news political parties throughout 2013). Retrieved from http://www.poltracking.com/publikasi/rilis-riset-dan-survei/8akun-twitter-sbyudhoyono.

[4] Bennet, W., L. 1998. News: The politics of illusion. (2nd ed.). New York: Longman.

[5] Borcher, T. 2005. Persuasion in the media age (2nd ed.). New York: McGraw Hill.

[6] Breit, E. 2011. On the discursive construction of corruption: A critical analysis of media text [Ebook]. Retrieved from http://www.helda.helsinki/

[7] Brown, E., Cloke, J, \& Rocha. (2011). Critical perspectives on corruption: An overview. Critical perspectives on international business, 7 (2). doi:10.1108/17422041111128203

[8] Dijk, A. T. (1988a). News analysis: Case studies of national and international news on the Press. Retrieved on March 16, 2013, from http://www.discourses.org/download/articles/.

[9] Dijk, A. T. (1988b). Critical discourse analysis. Retrieved on March 15, 2013, from http://www.discourses.org/download/articles/.

[10] Dijk, V., T. (2013). Discourse-cognition-society: Current state and prospects of the socio-cognitive approach to discourse. In C. Hart \& P. Cap (Ed). Contemporary studies in critical discourse analysis. Retrieved from http://www.discourses.org.

[11] Dharmasaputra, K. 2009. Media and corruption foklore. In Wijayanto \& R. Zachrie (Eds.), Indonesian Corruption: Cause, result and the eradication prospects (pp. 693-730). Jakarta: PT Gramedia Pustaka Utama.

[12] Eriyanto. 2001. Discourse analysis: An introduction of media text analysis. Yogyakarta: LKIS

[13] Fairclough, N. 1995. Critical discourse analysis. New York: Longman Publishing Group.

[14] Feraz, C., \& Finan, F. (2008). Exposing corrupt politicians: The effects of Brazil's publicly released audits on electoral outcomes. The Quarterly Journal of Economics, h. 703-746. 
[15] Laluhulu, S. (2013, Maret 7). KPK incar LHI jadi tersangka TPPU (KPK to seek LHI suspect of TPPU) . Retrieved from www.nasional.sindonews.com.

[16] Klitgaard, R. 1998. Fight against corruption. (Translator: Hermoyo). Jakarta: Yayasan Obor Indonesia.

[17] Kaligis, O., C. 2008. Praktik tebang pilih korupsi (Selective corruption eradication practice). Bandung: PT Alumni.

[18] Kim, H. (2014, January 21). Examining US news media discourses about North Korea: A corpus-based critical discourse analysis. Discourse Society, 25. doi:10.1037/1522-3736.3.1.31.

[19] Machin, D., \& Mayr, A. (2012). How to do critical discourse analysis. London: Sage Publication Ltd.

[20] Mahfud, M., D. (2013, Oktober 23). Korupsi dan biaya politik tinggi (Corruption and high political cost) [web log post]. Retrieved from http://www.mahfudmd.info.

[21] Mosco, V. 2009. The political economy of communication. (2nd. Ed). London: Sage Publication Ltd.

[22] Prasetyo, P. 2013. Membangun komitmen dan gerakan demokrasi untuk mencegah dan memberantas korupsi (Building commitments and democratic movement to prevent and combat corruption. In Kamil, S. (Ed.), Korupsi dan integritas dalam ragam perspektif (Corruption and integrity in a variety of perspectives) (pp. 3-23). Jakarta: PSIA UIN Jakarta.

[23] Reuter, T. 2014. Follow the money: Indonesian political parties and democracy. Retrieved from http://electionwatch.edu.au/indonesia-2014/follow-money-indonesian-political-parties-and-democracy.

[24] Riadi, S. (Oktober 17, 2013). Kasus hambalang, KPK tahan andi mallarangeng (Hambalang case, KPK detained Andi Mallarangeng. Retrieved from www.nasional.sindonews.com.

[25] Sahid, R., Syarief. (2013, February 4). Senior demokrat goyang Anas (Democrat Senior Cadres Shake Anas Position). Seputar Indonesia, p.1.

[26] Sahid, R. (2013, Februari 9). SBY Preteli Kekuasaan Anas (SBY disempower Anas). Seputar Indonesia, p.1.

[27] Semma, M. (2008). Negara dan korupsi: Pemikiran Mochtar Lubis atas negara, manusia Indonesia, dan perilaku politik (State and corruption: Mochtar Lubis' thoughts on the state, the Indonesian people, and political behavior). Jakarta: Yayasan Obor Indonesia.

[28] Shoemaker, P., \& Reese. S. (1996). Mediating the message: Theories of influences on mass media content. New York: Longman.

[29] Uu. (2012, January 27). Democrats to hold special congress if anas implicated. Retrieved from http://www.antaranews.com/en/news/79496/democrats-to-hold-special-congress-if-anas-implicated.Bowman, M., Debray, S. K., and Peterson, L. L. 1993. Reasoning about naming systems.

[30] Wijayanto. 2009. Mengukur tingkat korupsi (Measuring the corruption level). In Wijayanto \& R. Zachrie (Eds.), Korupsi mengorupsi Indonesia: Sebab, akibat dan prospek pemberantasan (Indonesian Corruption: Cause, result and the eradication prospects (pp. 58-111). Jakarta: PT Gramedia Pustaka Utama.

\section{Author' biography with Photo}

\section{Nostal Nuans Saputri}

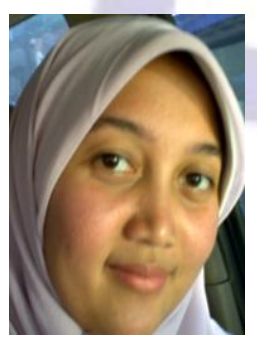

Nostal Nuans Saputri is an assistant lecturer in Communication Science Departement University of Brawijaya. She was graduated from English Literature Department at the State University of Malang (UM) in 2006 and worked as a journalist in Jawa Pos daily news at the same year until 2009. She, then pursued her master and granted a master degree in communication in 2014. Her research interests are linguistics, public health communication, and media research.

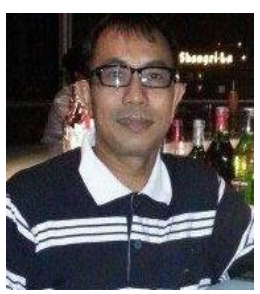

\section{Catur Suratnoaji}

Catur Suratnoaji is a lecturer in UPN Veteran Surabaya. He granted his undergraduate degree at Airlangga University, his master in Padjajaran University, and hold his Doctorate from University of Indonesia. Besides lecturing at the Communication Department, Catur also works as one commisioner of Indonesian Broadcasting Commission (KPI). His research interests are media and broadcasting regulation research. 